NEWS

\title{
Antarctica's impossible peaks come into view
}

\author{
Major polar project yields panorama of hidden mountains.
}

A mysteriously rugged mountain range hidden beneath east Antarctica's massive ice sheet has been revealed in all its topographic glory by an international research team. The findings may cause geologists to rethink their ideas about the continent's history.

The mountains, named the Gamburtsev range after Russian seismologist Grigoriy Gamburtsev, were discovered during the International Geophysical Year in 1957-58, but the peaks were little more than points on a map to geoscientists. In the International Polar Year (2007-09), which concludes at the beginning of March (see News Features, starting on page 1072), an expedition surveyed the Gamburtsevs in December 2008 and January 2009 to produce the first detailed portrait of the buried range. Radar, gravity and other data from roughly 130 airplane flights reveal a jagged landscape dotted with rivers and lakes, hundreds of metres beneath the icy surface.

"They are incredibly rough mountains they look like alligators' teeth," says US team co-leader Robin Bell of the Lamont-Doherty Earth Observatory in Palisades, New York. "It's a breathtaking landscape."

The rugged topography only

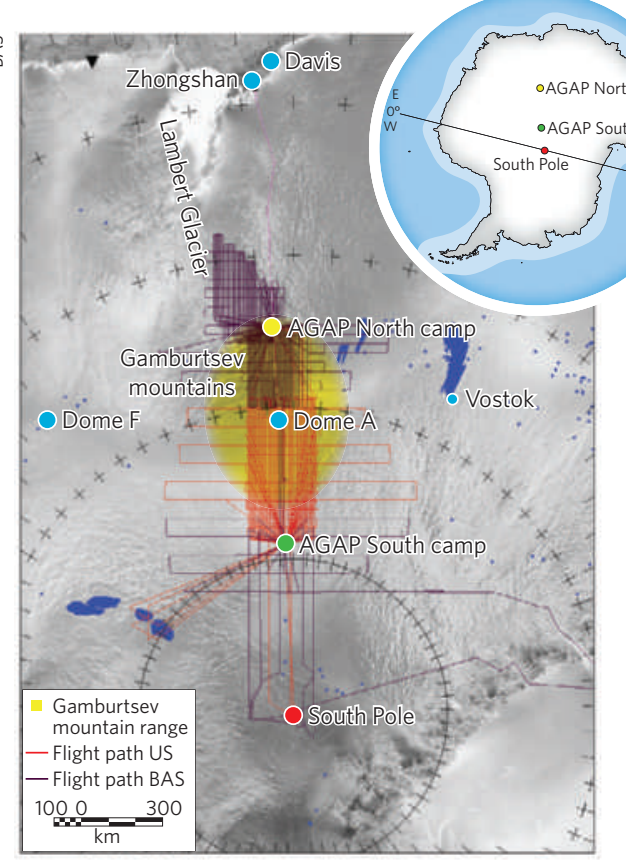

deepens the puzzle of how the Gamburtsevs formed, says Fausto Ferraccioli, UK team leader from the British Antarctic Survey in Cambridge, UK. The range sits in the middle of an ancient chunk of crust, where geologists had thought there had been no major tectonic activity for at least 540 million years. How long it's been there is a really good question," says John Goodge, a specialist in Antarctic geology at the University of Minnesota in Duluth, who was not involved in the project. If the range is indeed at least 540 million years old, then it is remarkably well preserved for its age.

Another possibility is that the Gamburtsevs formed much more recently, as a result of volcanic activity. But preliminary results from the expedition don't show the large magnetic anomalies that would typically be expected when flying over volcanic terrain, says Ferraccioli. And recent work looking at sediments that spilled off the Gamburtsevs, before the ice sheet formed on top, also suggests that the range is not volcanic in origin (T. van de Flierdt et al. Geophys. Res. Lett. 35, L21303; 2008).

Ian Dalziel, a geologist at the University of Texas in Austin, says there's no way to know exactly how old the Gamburtsevs are without drilling into them. To him, the ruggedness of the range is "a surprising result", with no convincing explanation so far. East Antarctica's ice sheet is thought to have formed roughly 35 million years ago, possibly nucleating atop the peaks of the Gamburtsevs.

The Antarctica's Gamburtsev Province Project (AGAP) was one of the major polar initiatives in the most recent Antarctic field season, involving researchers and support staff not only from the United States and Britain but also from Australia, Germany, China and Japan. The teams split into two camps; the US group worked from the south camp closer to the South Pole, whereas the UK team worked from the north camp on the other side of the Gamburtsevs (see map). Temperatures at both sites averaged $-30^{\circ} \mathrm{C}$; and bad weather at the south camp, at 3,500 metres

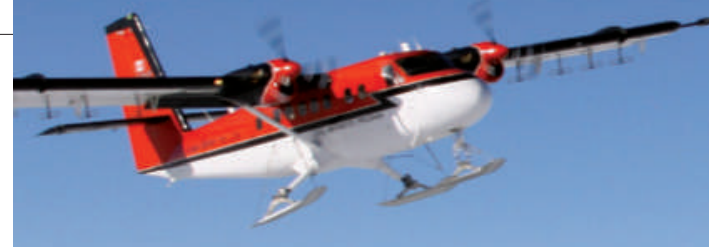

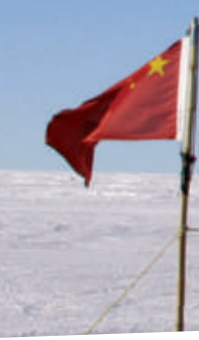
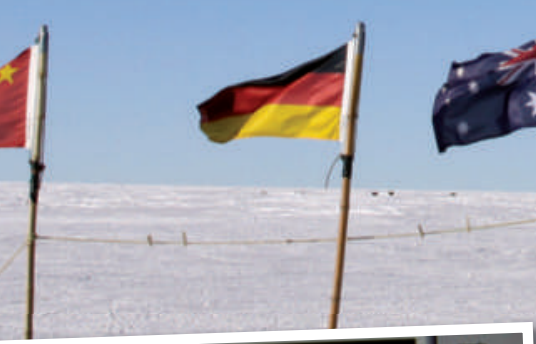

ind

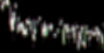
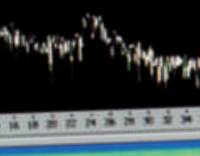

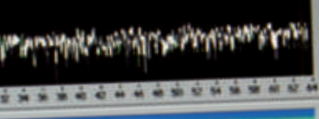

…iㅐ

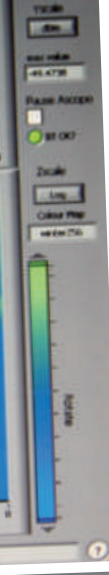

altitude, kept its two Twin Otter survey planes grounded for days at a time.

Eventually, the teams did manage to gather data while flying a total of 120,000 kilometres back and forth across the ice sheet in a dense grid; the US portion alone covered a region the size of California. The coverage is by far the most detailed look yet at the Gamburtsevs, although a Chinese expedition in the 2007-08 season gathered a line of radar data as it made its way from the coastal Zhongshan station to a new base China is constructing at Dome Argus (Dome A).

At their highest, the Gamburtsevs come within about 500 metres of the ice sheet's surface, says Bell. At the base of the mountains, the tremendous pressure of the overlying ice sheet and relatively warm temperatures has caused the ice to melt, creating lakes and rivers that can be seen in the radar data. As rivers cut ever deeper into the ground, the peaks could accordingly have been uplifted even higher, creating the dramatic topography seen today, says Ferraccioli. The Gamburtsev valleys are up to 700 metres deep from valley to peak, says Bell.

The data may also help ice-core specialists who are looking for a site to drill the next deep Antarctic core. Around Dome A - one primary target for drilling - the ice layers at 
